\title{
Detection of Red Tides in the Southwestern Florida Coastal Region Using Ocean Color Data
}

\author{
Peter C. Chu and Yu-heng Kuo
}

\begin{abstract}
Near real-time ocean color data from the Seaviewing Wide Field-of-view Sensor (SeaWiFS) was used to detect and trace harmful algal bloom (HAB) (also termed as red tides) in the Southwest Florida coastal water, which was treated as Case-2 water, i.e., its optical characteristics are influenced not only by phytoplankton and related particles, but also by other substances, that vary independently of phytoplankton, notably inorganic particles in suspension and yellow substances. Similar to Ahn et al. (2006), a red tide index was constructed from in-situ radiometric measurements of the three SeaWiFS bands centered at 411 $\mathrm{nm}, 510 \mathrm{~nm}$, and $555 \mathrm{~nm}$ to achieve derivation of indices that are then related to absorbing characteristics of harmful algae (i.e., Lw at $443 \mathrm{~nm}$ ) from which a best fit with a cubic polynomial function is obtained providing indices of higher ranges for $\mathrm{HABs}$ and lower and slightly reduced ranges for turbid and non-bloom water. In order to quantify the $\mathrm{HABs}$ in terms of chlorophyll (Chl), an empirical relationship is established between the $\mathrm{RI}$ and in-situ $\mathrm{Chl}$ in surface water which yields a Red tide index Chlorophyll Algorithm (RCA). In contrast, the band-ratio chlorophyll product of SeaWiFS in this complex coastal environment provided false information. The red tide that formed from November to December 2004 off SW Florida was revealed by RCA imagery, and was confirmed by field sampling to contain medium $\left(10^{4}\right.$ to $10^{5}$ cells $\left.\mathrm{L}^{-1}\right)$ to high $\left(>10^{5}\right.$ cells $\left.\mathrm{L}^{-1}\right)$ concentrations of the toxic Karenia brevis. The RCA imagery also showed that the bloom started in mid October south of Charlotte Harbor, and that it developed and moved to the south and southwest in the subsequent weeks. Our results show that the SeaWiFS data provides an unprecedented tool for research and managers to study and monitor algal blooms in coastal environments.
\end{abstract}

Key Words-Satellite ocean color; HABs; Red tide Index; Red tide index Chlorophyll Algorithm; OC4 bio-optical algorithm; SeaWiFS; Southwest Florida coastal water

\section{Introduction}

Over the last few decades, the coastal regions throughout the world have experienced incidences of harmful algal bloom (HAB) with potential threat to humans as well as marine organisms, owing to accelerated eutrophication from human activities and certain oceanic processes (Chu and Kuo, 2010). Accurate identification of these blooms remains a great challenge with the standard bio-optical algorithms applied to satellite ocean color data in optically complex coastal water containing high concentrations of the interfered dissolved organic and particulate inorganic materials (Ahn and Shanmugam, 2006).

Major HABs on the west Florida shelf (WFS), occurring in late fall and early spring, are primarily caused by the toxic species Karenia brevis, which can produce brevetoxins that accumulate in shellfish (e.g., oyster and clam); cause mortalities of fish, bird, marine mammals; irritate the eye and respiratory systems of animals including humans; represent serious hazard to human populations; and affect economic growth in the Gulf of Mexico (Anderson, 1995; Hu et al., 2005). The water becomes red, brown, or even black on WFS when the $\mathrm{K}$. brevis blooms.

Currently, remote sensing technology becomes very essential to detect, monitor and forecast their development and movement in order to mitigate the impacts of HABs, comparing to traditional ship-based field sampling and analysis due to space and temporal frequency. Major satellite ocean color sensors, such as Sea-viewing Wide Field-of-view Sensor (SeaWiFS), measure upwelled radiance for several narrow bands in the visible to near-infrared spectral range which are useful in identifying the properties of various colored constituents in the surface ocean, including phytoplankton, detritus, colored dissolved organic matter and suspended sediments (McClain et al., 1998). With these bands and adequate spatial resolution it may be possible to detect and trace HABs such as $\mathrm{K}$. brevis from space because their population is maximum at near surface waters $(0-15 \mathrm{~m})$.

Various colored constituents in the surface ocean determines the ocean color, i.e., the spectral waterleaving radiance, $L_{w}(\lambda)$. These constituents are water molecules, phytoplankton, detritus, colored dissolved organic matter, suspended sediments, and bottom reflectance (if the water is optically shallow). Chlorophyll (Chl) per cell for $\mathrm{K}$. brevis ranges from approximately $\sim 8.5 \mathrm{pg}$ for natural populations to $\sim 25 \mathrm{pg}$ for cultures (Evens et al., 2001). For a given cell density (10 pg/cell), concentration of $10^{4}$ cells L ${ }^{-1}$ would contains $\sim 0.1 \mathrm{mg} \mathrm{m}^{-3}$ of Chl, close to the background Chl levels in the open Gulf of Mexico. To be detectable by a sensitive satellite sensor, cell concentrations need to be $\sim 5 \times 10^{4}$ to $10^{5}$ cell $\mathrm{L}^{-1}\left(\sim 0.5\right.$ to $\left.1 \mathrm{mg} \mathrm{m}^{-3} \mathrm{Chl}\right)$. At these concentrations, K. brevis may cause fish kills (Steidinger et al., 1998). This causes the waterleaving radiance $\mathrm{L}_{\mathrm{w}}(\lambda)$ to be lower at blue wavelength $(443 \mathrm{~nm})$ than other phytoplankton (like diatom) due to their higher $\mathrm{Chl}$ specific absorption, and the water-leaving radiance at 
green wavelength $(555 \mathrm{~nm})$ to be higher than other phytoplankton due to the influence of strong pigment backscattering (Ahn et al., 2006).

Methods/algorithms for detecting HABs from ocean color $\left[\mathrm{L}_{\mathrm{w}}(\lambda)\right]$ have been developed mostly based on extensive in-situ bio-optical observations from optically less complex oceanic water (i.e., Case-1 water) and optical modeling of water properties. Cannizzaro et al. (2002) determined K. brevis has lower backscatter property than blooms of other diatom and dinoflagellate species and recently they proposed new algorithms based on in-situ data to use the backscattering/Chl ratio to differentiate HABs from other non-HABs. These methods/algorithms were usually directly used by satellite detection. For example, Steidinger and Haddad (1981) were among the first to use bio-optical Chl algorithm to detect $\mathrm{K}$. brevis bloom in WFS water from the Coastal Zone Color Scanner (CZCS). When SeaWiFS became operational, several studies appeared to have focused their efforts to exploit usefulness of satellite-derived $\mathrm{Chl}$ data to delineate the potential areas of $\mathrm{K}$. brevis blooms in the water of Gulf of Mexico (Hu et al., 2006). The routine monitoring has been initiated based on chlorophyll anomalies obtained from SeaWiFS image, which have served as indices of potential $\mathrm{K}$. brevis blooms in the Gulf of Mexico (Tomlinson et al., 2004).

Since most existing algorithms were obtained from insitu measurements for Case-1 waters, high Chl anomaly detected by these algorithms for Case- 2 waters is not always necessarily due to HABs because other non-HAB species can often exhibit similar pigment concentrations.

To overcome the limitations, Hu et al. (2005) showed that the patterns of HABs inferred from Moderate Resolution Imaging Spectroradiometer (MODIS) fluorescence line height (FLH) data were consistent with concurrent in-situ observations in the WFS waters where the traditional band ratio algorithm yielded false information about the blooms. However, the success of this approach may suffer from significant variations in $\mathrm{Chl}$ fluorescence efficiency depending on availability of nutrients, light intensity, temperature and physiological aspects of phytoplankton. Furthermore, in Case-2 waters weak Chl fluorescence emerges at the surface after complex interactions with suspended particulate materials through the turbid water column (Babin et al., 1996).

To identify HABs correctly in Case-2 Northeast-Asia coastal waters near Korea dominated mostly by Cochlodinium polykrikoides (hereafter referred to as $C$. polykrikoides), Alexandrium tamarense, Prorocentrum dentatum and Ceratium furca, Ahn and Shanmugam (2006) proposed a red-tide index (RI), which employs the water-leaving radiances $\left(\mathrm{L}_{\mathrm{w}}\right)$, collected from in-situ radiometric measurements of three SeaWiFS bands centered at $443 \mathrm{~nm}, 510 \mathrm{~nm}$ and $555 \mathrm{~nm}$, to achieve derivation of indices that are then related to absorbing characteristics of harmful algae $(443 \mathrm{~nm})$ from which a best fit with a cubic polynomial function with correlation coefficient of $\mathrm{R}^{2}=0.91$ is obtained. Question arises: can we use a similar approach (i.e., RI) to identify K. brevis in Case-2 WFS waters?

The main objectives of this research are as follows: (1) development and application of RI for correct identification of HABs (K. brevis) from satellite ocean color measurements in optically complex Case-2 water environments off the West Florida Coast, (2) extension of RI to delineate the patches of other phytoplankton blooms around coastal areas, (3) assessment of the applicability of standard spectral ratios bio-optical algorithms for detecting HABs in the WFS waters, and (4) validation of the presented methods using in-situ data and addressing the sources of error that limit the potential utility of satellite ocean color data for this application.

\section{Methods and data}

\subsection{In-situ bio-optical data}

In-situ bio-optical data was obtained from the SeaWiFS Biooptical Archive and Storage System (SeaBASS), which is maintained by the NASA Ocean Biology Processing Group (OBPG) to facilitate the ocean color satellite validation analyses. SeaBASS compiles a large set of coincident radiometric observations and phytoplankton pigment concentrations for use in biooptical algorithm development. Besides, the NASA bioOptical Marine Algorithm Data set (NOMAD) includes over 4459 stations world-wide of spectral water-leaving radiances, surface irradiances, and diffuse downwelling attenuation coefficients, encompassing chlorophyll a concentrations ranging from 0.012 to $72.12 \mathrm{mg} \mathrm{m}^{-3}$. Metadata, such as the date, time, and location of data collection, and ancillary data, including sea surface temperatures and water depths, accompany each record (Werdell et al., 2005).

In-situ bio-optical measurements were performed during 26 cruises through the years 1997-2006 (Table 1). There are 342 stations in the South West Florida coastal water (Fig. 1). Cell counts of K. brevis were obtained from the Florida Fish and Wildlife Research Institute (FWRI). The data were collected by FWRI, local agencies, volunteers, Mote Marine Laboratory, and University of South Florida researchers. The data were largely limited to observations within a few kilometers of the shoreline. Some of the FWRI samples were counted live, some using the Utermohl method with a light microscope that was sometimes inverted, and some samples were preserved in Lugol iodine solution for subsequent counting. Occasional samples from slightly deeper coastal water were collected through the MERHAB program coordinated by FWRI ( $\mathrm{Hu}$ et al., 2005). The bio-optical data collected were used in the derivation of RI algorithm for identifying HABs in the surface waters of the South West Florida. 


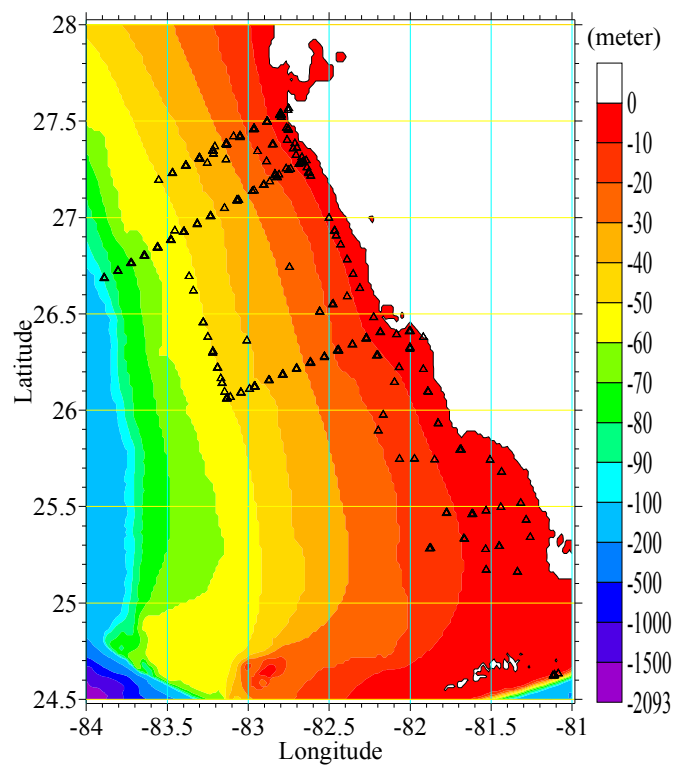

Fig. 1. Topography of the studied area (South West Florida coastal water) and the distribution of the NASA bio-Optical Marine Algorithm Data set (NOMAD) (342 stations).

Table 1

Southwest Florida in-situ bio-optical data of NOMAD

\begin{tabular}{|c|c|c|}
\hline Date & Cruise & No of data \\
\hline Jun 29 - Jul 01, 1997 & gom_jun 97 & 4 \\
\hline Mar $01-03,1999$ & eh0399 & 13 \\
\hline Jul $05-07,1999$ & eh0799 & 23 \\
\hline Sep $07-09,1999$ & eh0999 & 11 \\
\hline Nov $06-07,1999$ & eh1199 & 14 \\
\hline $\operatorname{Jan} 11,2000$ & eh0100 & 9 \\
\hline Mar $01-03,2000$ & eh0300 & 28 \\
\hline Aug $02-04,2000$ & eh0800 & 13 \\
\hline Oct $04-06,2000$ & eh1000 & 16 \\
\hline Nov $07-09,2000$ & eh1100 & 6 \\
\hline Feb $06-07,2001$ & eh0201 & 7 \\
\hline Apr $03-05,2001$ & eh0401 & 11 \\
\hline Jun $05-07,2001$ & eh0601 & 14 \\
\hline Jun 30 - Jul 02, 2001 & eh0701 & 16 \\
\hline Aug 01, 2001 & eh0801 & 7 \\
\hline Aug $28-30,2001$ & eh0901 & 25 \\
\hline Oct $01-02,2001$ & eh1001 & 5 \\
\hline Jun $29-$ Jul 01, 2002 & eh0702 & 20 \\
\hline Aug $06-08,2002$ & eh0802 & 13 \\
\hline Feb 10, 2003 & eb0203 & 1 \\
\hline Jul 26 - 29, 2004 & ecohab0407 & 13 \\
\hline $\operatorname{Jan} 19,2005$ & rt0501 & 4 \\
\hline Apr $25-28,2005$ & wfs0504 & 15 \\
\hline Oct 31 - Nov 03, 2005 & wfs0511 & 20 \\
\hline $\operatorname{Jan} 04-05,2006$ & wfs0601 & 14 \\
\hline Oct $02-05,2006$ & wfs0610 & 20 \\
\hline 26 cruises & total stations is & 342 \\
\hline
\end{tabular}

\subsection{SeaWiFS Imagery Data}

SeaWiFS ocean color instrument flown on Orbview-2, the SeaStar satellite in August 1997 by NASA, was specifically designed to provide near-global coverage every 2 days of upwelled radiance for eight narrow spectral channels $(\mathrm{nm})$ in the visible and near-infrared spectral range (402-422, 433-453, 480-500, 500-520, 545-565, 660-680, 745-785, and 845-885) with the spatial resolution of $\sim 1 \mathrm{~km} /$ pixel at nadir (Hooker et al., 1994). The SeaWiFS level $1 \mathrm{~A}$ data were ordered from NASA and processed to level 2 using NASA SeaDAS version 6.0. Fig. 2 illustrates the characteristics of complex Case-2 water environment of South West Florida coast by the Loop Current and its branches.

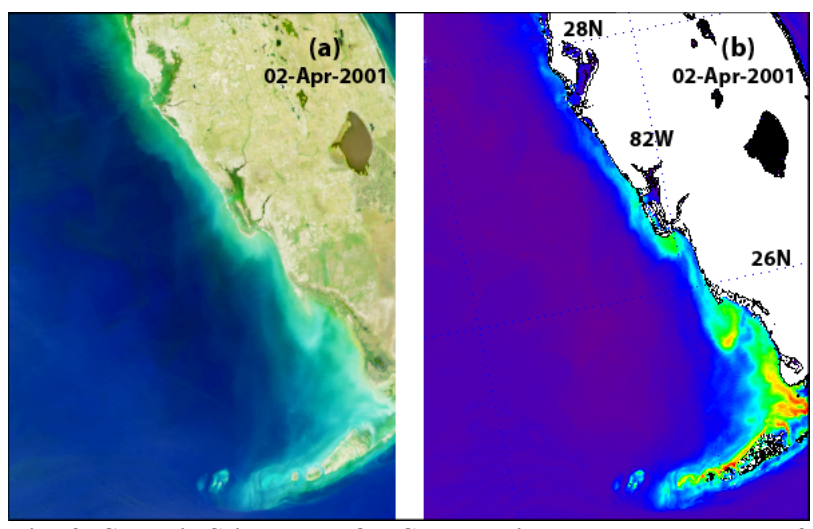

Fig. 2. SeaWiFS imagery for SW Florida coastal water on 2 April 2001. (a) Quasi true-color image of the SW Florida. (b) The color composite image from water-leaving radiance in three SeaWiFS wavelengths: $555 \mathrm{~nm}$ (Red), $490 \mathrm{~nm}$ (Green) and $412 \mathrm{~nm}$ (Blue), showing typical Case-2 water environments of the SW Florida dominated by very high concentrations of dissolved and particulate materials originating from the coastal processes.

\subsection{RI Method}

The OC4 algorithm is purely empirical in that it applies simple regression between the field determinations of pigment concentration and spectral ratios of ocean reflectance or normalized water-leaving radiance. The OC4 algorithm has been considered as standard method for satellite detection of HABs over the global waters.

Ahn and Shanmugam (2006) presented the RI concept, which differs from the standard spectral ratios algorithms that are sensitive not only to Chl but also to other water constituents such as suspended sediments (SSC) and dissolved organic matter (DOM). RI are achieved based on the principle that rapid growth of red tide organisms absorbs radiation in the lower green to blue wavelength part of spectrum while strongly reflecting radiation in the green wavelength part of the spectrum. In original form (Ahn and Shanmugam, 2006), the RI was defined by the ratio of two terms:

$[\operatorname{Lw}(510) / \mathrm{Lw}(555)-\mathrm{Lw}(443)]$ and $[\mathrm{Lw}(510) / \mathrm{Lw}(555)$ + Lw(443)]. To make unit consistency and to replace $443 \mathrm{~nm}$ with a shorter wave length $411 \mathrm{~nm}$, a new RI is defined by 


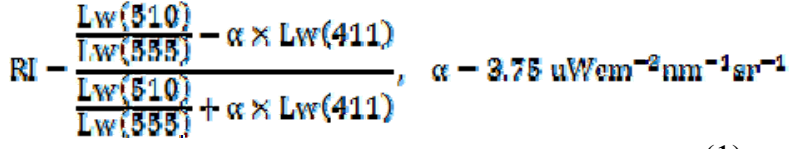

As Ahn and Shanmugam (2006) mentioned, this allows a good separation of red tides from other dominant optical types. RI values vary from -1 to +1 . A red tide index value of -1 means absence of harmful algal bloom $(\mathrm{HAB})$ and close to +1 indicates the highest possible of HABs. For blue waters with less phytoplankton and other agents such as nanophytoplankton and heterotrophic bacteria and viruses and waters with substances other than phytoplankton such as suspended inorganic particles (SSC) and dissolved organic matter (DOM) (and perhaps even a bottom reflectance) that make a significant contribution to the optical properties of the coastal waters (Ahn and Shanmugam, 2006; Arnone et al., 2004; Sathyendranath, 2000).

\subsection{Relationship between RI and $\operatorname{Lw}(443)$ from In-} situ Data

The in-situ data (342 stations) depicted in Table 1 and Fig. 1 was used to obtain relationship between RI and Lw(443). Fig. 3 shows the scatter diagram of the two parameters RI and X $[=\mathrm{Lw}(443)]$ with the correlation coefficient of $\mathrm{R}^{2}=0.90$,

$$
\mathrm{RI}_{(\mathrm{D})}=10^{\left(a_{0}-a_{1} X+a_{2} X^{2}-a_{3} X^{3}\right)}
$$

with the coefficients are $a_{0}=0.6042, a_{1}=1.6657, a_{2}=$ $0.9212, a_{3}=0.2011$.

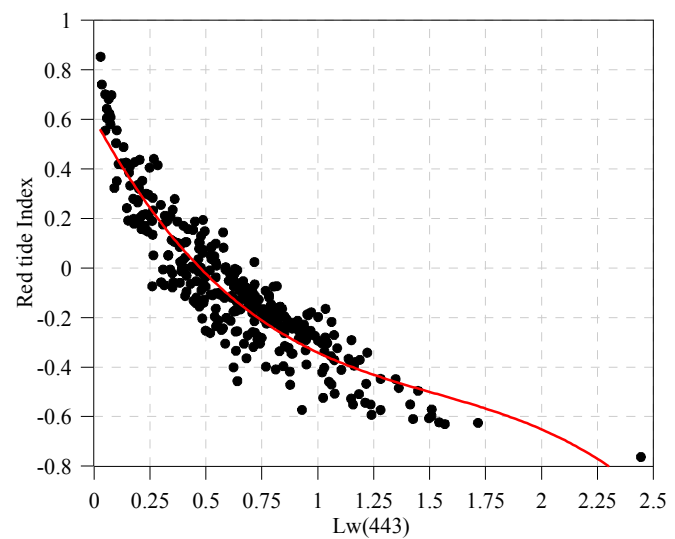

Fig. 3. Scatter plot of Red tide Index (RI) calculated using equation (1) versus $L_{w}$ at $443 \mathrm{~nm}$ data $(N=342)$ collected from in-situ measurements over the SW Florida of NASA bio-Optical Marine Algorithm Data set (NOMAD).

2.4. Relationship between $C h l$ and $R I_{(D)}$ from Insitu Data

Similarly, the in-situ data (342 stations) was used again to obtain relationship between $\mathrm{Chl}$ concentration and $\mathrm{RI}_{(\mathrm{D})}$. Fig. 4 shows the scatter diagram of the two parameters $\mathrm{Chl}$ and $\mathrm{RI}_{(\mathrm{D})}$ with the correlation coefficient of $\mathrm{R}^{2}=0.85$,

$$
<\mathrm{Chl}>\left(\mathrm{mg} \mathrm{m}^{-3}\right)=b_{0} \exp \left[b_{1} R I_{(D)}\right],
$$

(1) with the coefficients of $b_{0}=0.5970, b_{1}=0.7518$.

Eq.(3) shows that in-situ Chl concentrations correspond best with an exponential rather than a linear function of $\mathrm{RI}_{(\mathrm{D})}$. The derived $\mathrm{Chl}$ values are red tide specific and therefore can be used to quantitatively detect and assess the potential areas of HABs in optically complex waters. Such calculation (3) is called the Red tide index Chlorophyll Algorithm (RCA)

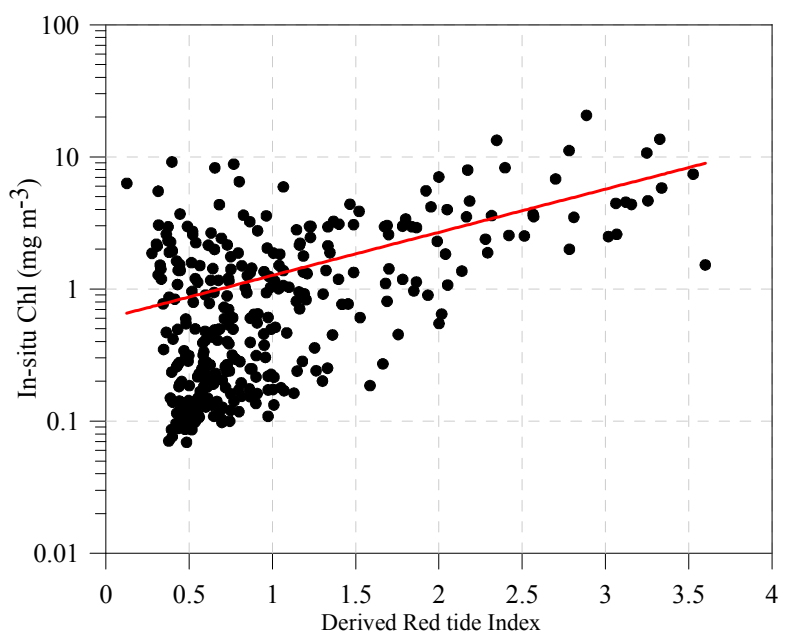

Fig. 4. $\mathrm{RI}_{(\mathrm{D})}$ versus log-transformed Chl data $(N=342)$ collected from in-situ measurements over the $\mathrm{SW}$ Florida of NASA bio-Optical Marine Algorithm Data set (NOMAD).

\section{Red-tide Detection by RCA}

The procedure for construct RCA images from the SeaWiFS data is listed as follows: (1) Compute RI(D) from Lw(443) using (2); and (2) calculate $<\mathrm{Chl}>$ from $\mathrm{RI}_{(\mathrm{D})}$ ) using (3). The red-tide event was detected from the SeaWiFS data with RCA during late 2004. Several suspicious patterns were identified with the images in mid to late October 2004 (red arrows in Figs. 5a and 5b). In situ data showed that the bloom contained high concentrations $\left(>10^{5}\right.$ cells $\left.\mathrm{L}^{-1}\right)$ of $\mathrm{K}$. brevis by mid-late November (Figs. 5d and 5e), when mortality of large fish ( $>1$ foot long) and of at least four dolphins was reported by local fishermen. From early November to mid December (Figs. 5c-5i), the bloom drifted southward and expanded to form a large clear patch to off shore water around $25.5 \mathrm{~N} 82.5 \mathrm{~W}$.

On 19 October 2004, most waters immediately off Charlotte Harbor did not contain toxic phytoplankton, but a small near shore patch (marked with a red arrow in Fig. 5a) contained high concentrations of $\mathrm{K}$. brevis. Clearly, RCA data alone are insufficient to identify whether a bloom is toxic or not. However, most highRCA features in the image series were confirmed by the field sampling results to contain medium to high concentrations of K. brevis. Similarly, the low-RCA waters were confirmed to contain low or undetectable concentrations of $\mathrm{K}$. brevis. Considering the much- 
larger, spatially coherent features identified by the satellite Chl data, the example suggests that RCA data provide a better means to detect and trace South West Florida coastal water red tides.

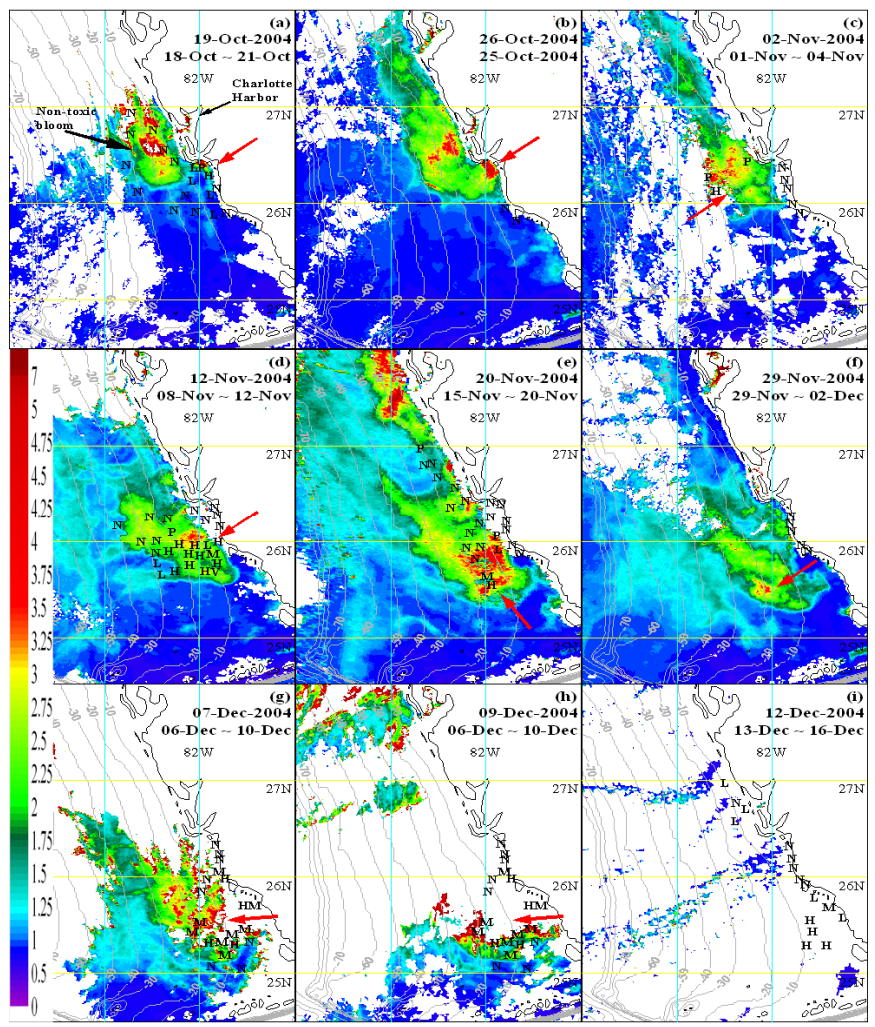

Fig. 5. Red tide index Chlorophyll Algorithm (RCA) from equation (3) image series show the development and progression of a harmful algal bloom or red tide (identified by red arrows). Overlaid on the images are water sample analysis results from the Florida Fish and Wildlife Research Institute (FWRI). The second date on each image indicates the in situ sample collection time. Letters represent different $K$. brevis concentrations in cells $L^{-1}$ as follows: $N$ not present or below detection limit; $P$ - present $\left(<10^{3}\right) ; \mathrm{L}-$ low (between $10^{3}$ and $10^{4}$ ); $\mathrm{M}-$ medium (between $10^{4}$ and $10^{5} ; \mathrm{H}-$ high (between $10^{5}$ and $\left.10^{6}\right) ; \mathrm{V}-$ very high $\left(>10^{6}\right)$.

\section{Conclusions}

Our approach to the red tide detection problem is based on RI algorithms developed by using in-situ biooptical data collected from Southwest Florida coastal regions (Case-2 water). Extraction of waterleaving radiances in all SeaWiFS bands was successful and spectral shape remained unaltered by the application of SSMM in optically complex waters (Ahn and Shanmugan, 2006). The results of our investigation clearly show the advantages of applying RI and RCA algorithms over traditional spectral ratios methods to correctly identify the potential areas of $\mathrm{HABs}$ and distinguish other phytoplankton blooms from non-bloom oceanic waters. The spatial patterns of red tides inferred from RI and RCA algorithms appeared to be more consistent with in-situ data than those from standard OC4 and LCA algorithms. We plan to extend our algorithms for detecting HABs to other regions and continue to future refine and validate previously established methods.

\section{Acknowledgments}

We thank the NASA Ocean Biology Processing Group (OBPG) for providing high resolution ocean color data. This research was funded by the Naval Oceanographic Office.

\section{References}

Ahn, Y. H., \& Shanmugam, P., (2006). Detecting the red tide algal blooms from satellite ocean color observations in optically complex Northeast-Asia coastal waters. Remote Sensing of Environment, 103, 419-437.

Anderson, D. M. (1995). ECOHAB: The Ecology and Oceanography of Harmful Algal Blooms, a national research agenda. Woods Hole Oceanog. Woods Hole, MA' Institute, $67 \mathrm{pp}$.

Arnone, R. A., Wood, A. M., \& Gould, R. W. (2004). The evolution of optical water mass classification. Oceanography, 17(2), 15.

Babin, M., Morel, A., \& Gentili, B. (1996). Remote sensing of sea surface suninduced chlorophyll-a fluorescence: Consequences of natural variation in the optical characteristics of phytoplankton and the quantum yield of chlorophyll a fluorescence. International Journal of Remote Sensing, 17, 2417-2448.

Chu, P.C., and Y.-H. Kuo, 2010: Nutrient pumping/advection by propagating Rossby waves in the Kuroshio Extension. Deep-Sea Research II, doi:10.1016/ j.dsr2.2010.04.007.

Evens, T. J., Kirkpatrick, G. J., Millie, D. F., Chapman, D. J., \& Schofield, O. M. E. (2001). Photophysiological responses of the toxic red-tide dinoflagellate Gymnodinium breve (Dinophyceae) under natural sunlight. Journal of Plankton Research, 23, 1177- 1193.

Hooker, S. B., McClain, C. R., Firestone, J. K., Westphal, T. L., Yeh, E. N., \& Geo, Y. (1994). The SeaWiFS Bio-optical Archive and Storage System (SeaBASS): Part 1. NASA Tech. Memo. 104566, vol. 20. (p. 37). Greenbelt' NASA Goddard Space Flight Center.

Hu, C., Muller-Karger, F. E., Taylor, C., Carder, K. L., Kelble, C., Johns, E., et al. (2005). Red tide detection and tracing using MODIS fluorescence data: a regional example in SW Florida coastal waters. Remote Sensing of Environment, 97, 311-321.

International Ocean-Colour Coordinating Group, 2000:

Remote sensing of ocean colour in coastal, and other optically-complex, waters. IOCCG Report 3, pp. 145. http://www.ioccg.org/reports/report3.pdf

McClain, C. R., Cleave, M. L., Feldman, G. C., Gregg, W. W., Hooker, S. B., \& Kuring, N. (1998). Science 
quality SeaWiFS data for global biosphere research. Sea Technology, 39, 10- 16.

Sathyendranath, S. (2000). Remote sensing of ocean color in coastal and other optically complex waters. IOCCG Report, Vol. 3, Dartmouth, Nova Scotia, IOCCG Project Office, pp. 140.

Steidinger, K. A., \& Haddad, K. (1981). Biologic and hydrographic aspects of red tides. Bioscience, 31(11), 814-819.

Steidinger, K. A., Vargo, G. a., Tester, P. A., \& Tomas, C. R. (1998). Bloom dynamics and physiology of Gymnodinium breve, with emphasis on the Gulf of Mexico. In E. Anderson, D. Cembella, \& M. Hallengraff (Eds.), Physiological ecology of harmful algal blooms (pp. 135-153). New York' Springer-Verlag.

Tomlinson, M. C., Stumpf, R. P., Ransibrahmanakul, V., Turby, E. W., Kirkpatrick, G. J., Pederson, B. A., et al. (2004). Evaluation of the use of SeaWiFS imagery for detecting Karenia brevis harmful algal blooms in the eastern Gulf of Mexico. Remote Sensing of Environment, 91, 293- 303.

Werdell, P. J., \& Bailey, S. W. (2005). An improved insitu bio-optical data set for ocean color algorithm development and satellite data product validation. Remote Sensing of Environment 98, $122-140$. 